\title{
GAS TONOMETRY FOR EVALUATION OF GASTROINTESTINAL MUCOSAL PERFUSION. EXPERIMENTAL MODELS OF TRAUMA, SHOCK AND COMPLEX SURGICAL MANEUVERS - PART $1^{1}$
}

\author{
Luiz Francisco Poli de Figueiredo \\ Eliezer Silva ${ }^{3}$ \\ Ruy Jorge Cruz Jr ${ }^{4}$ \\ Maurício Rocha e Silva ${ }^{5}$
}

Poli de Figueiredo LF, Silva E, Cruz Jr RJ, Rocha e Silva M. Gas tonometry for evaluation of gastrointestinal mucosal perfusion: experimental models of trauma, shock and complex surgical maneuvers. Part 1. Acta Cir Bras [serial online] 2002 Jul-Aug;17(4). Available from URL: http://www.scielo.br/acb

\begin{abstract}
Substantial clinical and animal evidences indicate that the mesenteric circulatory bed, particularly the gut mucosa, is highly vulnerable to reductions in oxygen supply and prone to early injury in the course of hemodynamic changes induced by trauma, shock, sepsis and several complex surgical maneuvers. Gut hypoxia or ischemia is one possible contributing factor to gastrointestinal tract barrier dysfunction that may be associated with the development of systemic inflammatory response and multiple organ dysfunction syndrome, a common cause of death after trauma, sepsis or major surgeries. Monitoring gut perfusion during experiments may provide valuable insights over new interventions and therapies highly needed to reduce trauma and sepsis-related morbidity and mortality. We present our experience with gas tonometry as a monitor of the adequacy of gastrointestinal mucosal perfusion in clinical and experimental models of trauma, shock and surgical maneuvers associated with abrupt hemodynamic changes, such as aortic occlusion and hepatic vascular exclusion. Next issue we will be presenting our experience with gas tonometry in experimental and clinical sepsis.
\end{abstract}

KEY WORDS - Ischemia. Reperfusion. Catecholamines. Tonometry. Gut mucosa. Hemorrhage. Multiple organ failure. Tonometry. Shock. Multiple trauma.

\section{INTRODUCTION}

Shock, trauma, sepsis and major surgeries are associated with multiple organ dysfunction syndrome, in part as a consequence of blood flow redistribution, resulting in hypoperfusion of regional vascular beds. ${ }^{1}$
However, there is a great deal of controversy on whether tissue distress observed under these conditions is caused exclusively by microcirculatory hypoxia or by disturbances in cellular metabolic pathways. Several authors have shown that despite an apparently sufficient global oxygen delivery, signs of hypoxia and/or

1. Studies performed at the Division of Applied Physiology, Dept. of Cardiopneumology, Heart Institute, InCor, Univ. São Paulo Medical School, São Paulo, Brazil.

2. Professor, Internal Medicine, Univ. Santo Amaro and Posdoctoral Fellow, Heart Institute, InCor, Univ. São Paulo Medical School.

3. Associate Professor, Division of Applied Physiology, Heart Institute, InCor, Univ. São Paulo Medical School, and Department of Surgery, UNIFESP/EPM, São Paulo, Brazil.

4. Doctoral Fellow, Division of Applied Physiology, Heart Institute, InCor, Univ. São Paulo Medical School.

5. Chairman, Dept. of Cardiopneumology, Heart Institute, InCor, Univ. São Paulo Medical School. 
metabolic dysfunction may persist. The availability of techniques to assess regional hemodynamic and oxygenrelated variables has highlighted the inadequacy of the information obtained by global measurements. ${ }^{2}$

There are several convincing reasons to concentrate on the gut as the organ to detect occult tissue hypoxia during an apparent hemodynamic stability. ${ }^{3}$ Intestinal mucosal cells are normally under a low oxygen tension, because effective hematocrit within the villi is decreased due to a phenomenon called "plasma skimming"4 and the villi have a peculiar microvascular architecture, characterized by a countercurrent exchange of oxygen from arteriole to adjacent venule along its length (Figure 1). Under normal conditions, this shunting of oxygen is not harmful to the villi. However, in conditions in which blood flow to the gut becomes greatly curtailed, such as in circulatory shock, the oxygen deficit in the tips of the villi can become so severe that they can suffer ischemic death and disintegrate. ${ }^{4,5}$

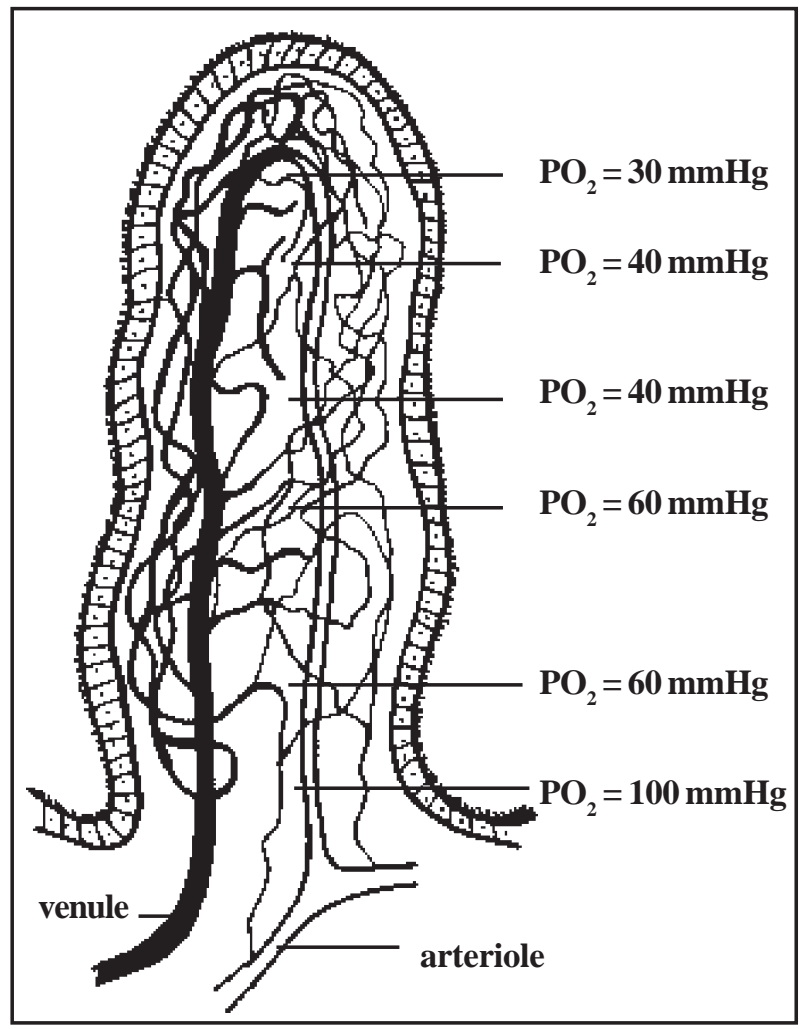

Figure 1 - Countercurrent exchange of $\mathrm{O}_{2}$ between arteriole and venule within the intestinal villi, showing the progressive decrease in arteriolar $\mathrm{PaO}_{2}$.

Additionally, the gut is the organ with the highest critical oxygen delivery ( $\mathrm{DO}_{2}$ ) in the body. ${ }^{6}$ Since the gut is richly innervated by the sympathetic nerve system, the response to a decrease in global $\mathrm{DO}_{2}$, such as during hemorrhage (Figure 2), aortic occlusion (Figure 3) or hepatic vascular exclusion (Figure 4), intestinal vasoconstriction is greater than most vascular beds, when blood is redistributed to the vital organs, and may persist when systemic hemodynamic variables have been reestablished (Figures 2 and 4). These conditions jeopardize the integrity of gut mucosal cells, predisposing to increases in gut permeability and translocation of bacteria and their toxins. Consequently, a systemic inflammatory response, incriminated in the development of multiple organ failure, ${ }^{4,7}$ is induced by regional cytokine synthesis and several other inflammatory mediators, released by hepatic and systemic mononuclear cells. ${ }^{4}$

Although several techniques have been proposed to measure the adequacy of gut perfusion, ${ }^{8}$ only gas tonometry is available for bedside clinical use. It is a minimally invasive technique that measures gut mucosal $\mathrm{PCO}_{2}$ through a modified nasogastric tube with a $\mathrm{CO}_{2}-$ permeable balloon at its tip. ${ }^{9}$ Because of the inverse relationship between tissue $\mathrm{PCO}_{2}$ and local blood flow, gas tonometry has emerged as a tool for tissue perfusion assessment.

In this review, we highlight the current knowledge regarding gas tonometry as a tool to better understand the pathophysiology of tissue oxygen distribution during shock states and principally, sepsis. Moreover, we will focus on the use of gas tonometry to determine the role of gut mucosal acidosis during surgical maneuvers and potential therapeutic interventions, such as fluid resuscitation and vasoactive drugs.

\section{THE TONOMETRIC METHOD}

Since the early part of this century, it has been shown that in a hollow viscus, tissue $\mathrm{CO}_{2}$ diffuses from regional blood vessels into its lumen. ${ }^{10}$ In 1959, Boda and Muranyi ${ }^{11}$ published the concept of gastric tonometry. They demonstrated a close relationship between gastric $\mathrm{PCO}_{2}$ and end-tidal $\mathrm{CO}_{2}$ and, therefore, to arterial $\mathrm{PCO}_{2}$, using a catheter with a balloon filled with room air into the stomach of healthy volunteers to measure $\mathrm{PCO}_{2}$ of the gas sampled from the balloon. By introducing a saline sample into the gallbladder or urinary bladder lumen, Bergofsky ${ }^{12}$ demonstrated that $\mathrm{PCO}_{2}$ equilibrate with organs' wall $\mathrm{PCO}_{2}$. A more rapidly equilibration between fluid $\mathrm{PCO}_{2}$ and venous $\mathrm{PCO}_{2}$, drained from an ileal loop mucosa, was observed by Dawson et al. ${ }^{13}$ More recently, the ability to measure $\mathrm{PCO}_{2}$ by the tonometric method was clearly validated in vitro using solutions with known $\mathrm{PCO}_{2}$ concentrations. ${ }^{14}$ 

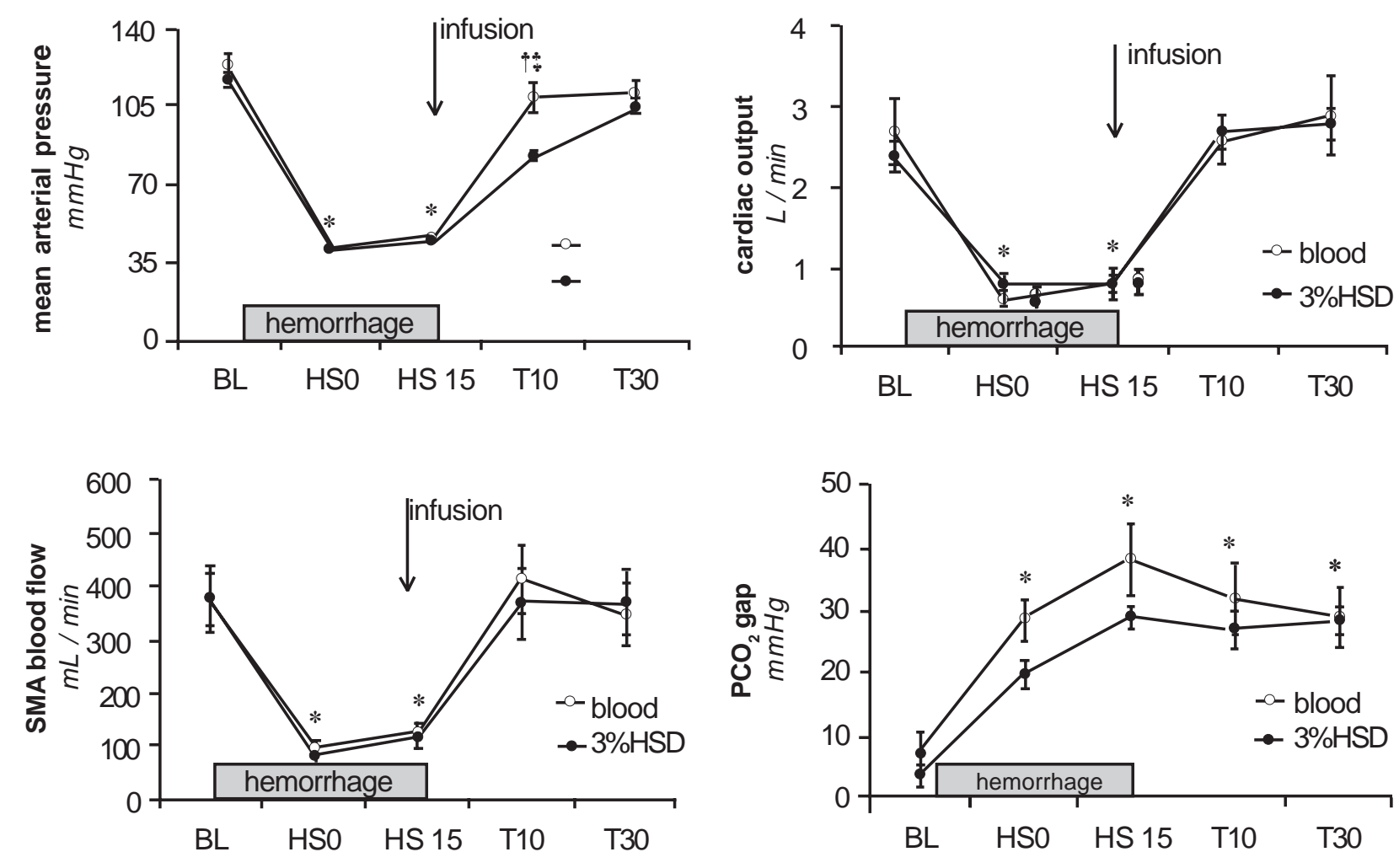

Figure 2 - Mean arterial pressure (MAP), cardiac output (CO), superior mesenteric artery blood flow (SMA) and gastric-arterial $\mathrm{CO}_{2}\left(\mathrm{PCO}_{2}\right.$-gap) in a controlled hemorrhage model in dogs. Blood was removed at a $20 \mathrm{~mL} / \mathrm{min}$ rate to a mean arterial pressure of $40 \mathrm{mmHg}$ (HSO), and maintained at these levels for $15 \mathrm{~min}$ (HS15). Dogs were randomized according to fluid solution infused. $B L O O D(\mathrm{n}=9)$ received total shed blood retransfusion during $30 \mathrm{~min}(\mathrm{~T} 10$ and $\mathrm{T} 30) .3 \% \mathrm{HSD}(\mathrm{n}=8)$ received $3 \% \mathrm{NaCl} / 10 \% \mathrm{dextran}$ 40 , in a volume equivalent to $1 / 4$ of total shed blood in a 4 -min bolus injection and followed for $30 \mathrm{~min}$ (T10 and T30). Hemorrhage and shock promoted significant reductions on MAP, $\mathrm{CO}, \mathrm{SMA}$ and marked increases in $\mathrm{PCO}_{2}$ gap. Treatment with total shed blood or smaller volumes of 3\% HSD restored hemodynamic parametes, except for $\mathrm{PCO}_{2}-$ gap, which remained elevated, in spite of an apparent successful fluid resuscitation. [adapted from Poli de Figueiredo LF, Silva E, Cruz Jr RJ et al. Sustained gastric mucosal acidosis despite rapid global and regional hemodynamic restoration after hemorrhage and resuscitation with blood or hypertonic/ hyperoncotic solution. J Trauma, submitted]

Fiddian-Green et al. ${ }^{15}$ adopted the saline tonometric technique for the assessment of gut luminal $\mathrm{PCO}_{2}$ and extended its use to the calculation of gastrointestinal intramucosal $\mathrm{pH}(\mathrm{pHi})$. They assumed that the arterial bicarbonate level, measured by arterial blood gas analyzer, was the same as the intramucosal bicarbonate, and calculated pHi by the Henderson-Hasselbach equation as follows:

$$
\mathrm{pHi}=6.1+\log \quad\left[\mathrm{HCO}_{3}^{-}\right] /\left[\mathrm{PCO}_{2}\right] \times 0.031
$$

where $\left[\mathrm{HCO}_{3}^{-}\right]$is the bicarbonate concentration, calculated from arterial $\mathrm{PCO}_{2}$ and $\mathrm{pH},\left[\mathrm{PCO}_{2}\right]$ is the $\mathrm{CO}_{2}$ tension, measured on saline aspirated directly from the stomach, and 0.031 is the solubility coefficient for $\mathrm{CO}_{2}$ in plasma. Subsequently, this technique was modified to use a $\mathrm{CO}_{2}$-permeable, silicone balloon catheter, from which aliquots of saline could be withdrawn and evaluated by routine blood gas analyzers.
Validity and reproducibility of $\mathrm{pHi}$, measured by gastric tonometry, were examined in experimental models of sepsis, graded hemorrhage and mesenteric artery occlusion; compared to the $\mathrm{pH}$ measured by implanted microelectrodes, $\mathrm{pHi}$ matched closely. ${ }^{16-20} \mathrm{It}$ has been also shown, by several different techniques, that decreases in blood flow to the gut are paralleled by concordant decreases in $\mathrm{pHi}$ and increases in tissue $\mathrm{PCO}_{2}$ determined by tonometry. ${ }^{19,21-28}$ Also, in critically ill patients, mucosal gastric perfusion, measured by laser Doppler ${ }^{29}$ or reflectance spectroscopy ${ }^{30}$ was lower when an increased $\mathrm{PgCO}_{2}-\mathrm{PaCO}_{2}$ gradient or a subnormal $\mathrm{pHi}$ was present.

Hence, $\mathrm{PCO}_{2}$ estimated by tonometry should correspond to that of tissue $\mathrm{PCO}_{2}$. When fluid is instilled into the lumen of a hollow organ, gaseous $\mathrm{CO}_{2}$ equilibrates with $\mathrm{CO}_{2}$ in interstitial fluid and cells in the superficial layers of the organs wall. ${ }^{31}$ However, the stomach may be an exception, because $\mathrm{PCO}_{2}$ of gastric 



Figure 3 - Mean arterial pressure (MAP), cardiac output (CO), superior mesenteric artery blood flow (SMA) and gastric-arterial $\mathrm{CO}_{2}\left(\mathrm{PCO}_{2}\right.$-gap) in a controlled hemorrhage model, followed by ischemia and reperfusion induced by a transfemoral supraceliac aortic balloon occlusion. Blood was removed at a $20 \mathrm{~mL} / \mathrm{min}$ rate to a mean arterial pressure of $40 \mathrm{mmHg}$ (HS0), and maintained at these levels for $30 \mathrm{~min}$ (HSO and HS30). Dogs were randomized to CT (controls, n=7), which were followed for 90 min, or TAO $(\mathrm{n}=7)$, supraceliac aortic occlusion for $30 \mathrm{~min}$, followed for $60 \mathrm{~min}$ after reperfusion. Hemorrhage and shock promoted significant reductions on MAP, CO, SMA and marked increases in $\mathrm{PCO}_{2}$ gap. Aortic occlusion restored mean arterial but induced further decreases in SMA blood flow and increases in $\mathrm{PCO}_{2}$ gap. During reperfusion, hemodynamic parametes were similar between groups, while greater increase in $\mathrm{PCO}_{2}$ - gap was observed in animals submitted to aortic occlusion. [adapted from Cruz Jr RJ, Poli de Figueiredo LF, Rocha e Silva M. Splanchnic blood flow, oxygen metabolism and $\mathrm{PCO}_{2}$-gap after aortic occlusion during hemorrhagic shock. Eur J Surg, submitted]

juice may, in some instances, exceed $\mathrm{PCO}_{2}$ of gastric wall and gastric venous blood $\mathrm{PCO}_{2} \cdot \mathrm{PCO}_{2}$ is also generated into the gastric lumen, from the $\mathrm{H}^{+}$ neutralization by the bicarbonate contained in the gastric juice or in the backflow of duodenal fluid. Back diffusion of $\mathrm{CO}_{2}$ into the gastric mucosa itself increases gastric wall $\mathrm{PCO}_{2}$, independently of gastric mucosal blood flow. ${ }^{32-34}$ After $\mathrm{H}_{2}$ blockade by cimetidine, $\mathrm{H}^{+}$production by the stomach is reduced, and $\mathrm{PCO}_{2}$ of gastric luminal fluid and that of gastric venous blood approximate each other. Accordingly, $\mathrm{H}^{+}$of gastric juice interferes with tonometric measurement of $\mathrm{PCO}_{2}$, and routine $\mathrm{H}_{2}$ blockade is therefore recommended to minimize this effect. ${ }^{33}$ Although many critically ill patients are treated with $\mathrm{H}_{2}$ receptor-blocking agents for the prevention of stress ulceration, their benefits are disputed. There are adverse effects of $\mathrm{H}_{2}$ blockade in such settings, especially an increased risk of nosocomial pneumonia. ${ }^{35}$ To avoid the short-comes (food, $\mathrm{H}_{2}$ blockers, duodenal reflux) of the gastric tract for mucosal $\mathrm{PCO}_{2}$ measure- ments, $\mathrm{PCO}_{2}$ tonometry have been evaluated in several other tissues such as sublingual, ${ }^{36-38}$ esophageal, ${ }^{22}$ and bladder mucosa (Figure 5). ${ }^{39}$ The feasibility and accuracy of these techniques remains to be validated.

There are limitations inherent to the use of saline samples, such as the time interval required for $\mathrm{CO}_{2}$ equilibration between the saline into the tonometer's balloon and the gastric wall. Experimentally, it has been shown that the level of tissue $\mathrm{PCO}_{2}$ has little effect on the equilibration period. ${ }^{24,40}$ The manufacturer recommends mathematical corrections to adjust for incomplete equilibration, which is usually inversely related to the period of equilibration. However, these corrections represent average values rather than values indicating the time required for partial equilibration for an individual patient. Another source of error is that, when saline $\mathrm{PCO}_{2}$ is measured with several blood gas analyzers, a wide variation is observed, particularly at higher $\mathrm{PCO}_{2}$ levels, underestimating balloon $\mathrm{PCO}_{2}{ }^{41}$ By using other solutions instead of saline, errors in $\mathrm{PCO}_{2}$ 

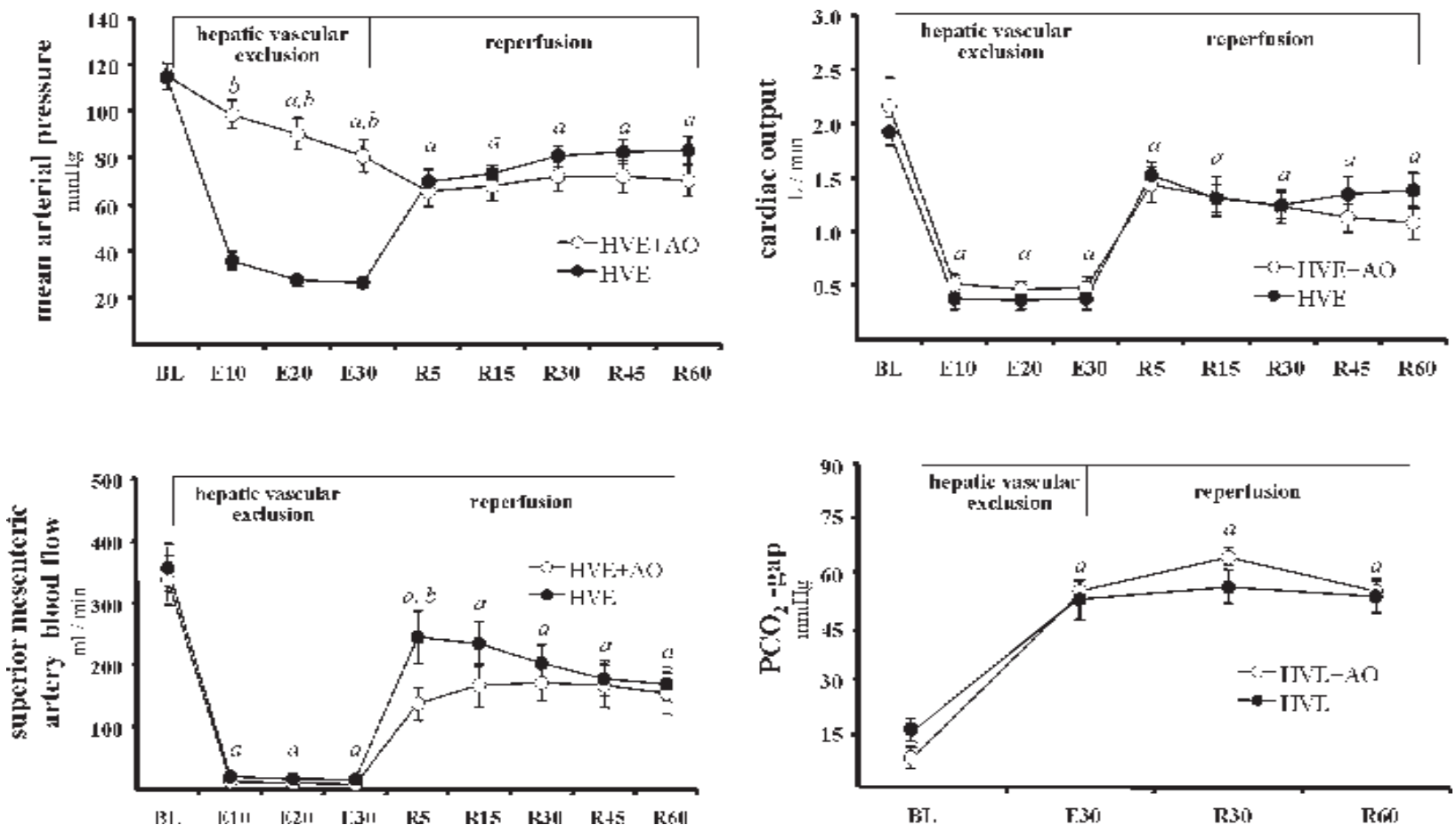

Figure 4 - Mean arterial pressure (MAP), cardiac output (CO), superior mesenteric artery blood flow (SMA) and gastric-arterial $\mathrm{CO}_{2}\left(\mathrm{PCO}_{2}\right.$-gap) in dogs randomized to a hepatic vascular exclusion (HVE, $\mathrm{n}=13$ ) or HVE with supraceliac aortic occlusion (HVE+AO) for $30 \mathrm{~min}$ (E10-E30), followed for reperfusion (R10-R60). Portal triad, supra and infrahepatic inferior vena cava crossclamping promoted significant decreases in MAP, $\mathrm{CO}$ and SMA blood flow, while $\mathrm{PCO}_{2}$-gap increased. Concomitant aortic occlusion prevented severe hypotension. Reperfusion promoted partial restoration of MAP, CO and SMA blood flows, while $\mathrm{PCO}_{2}$-gap remained similarly increased in both groups. [adapted from Cruz Jr RJ, Poli de Figueiredo LF, Braz JL et al. Systemic and regional effects of supraceliac aortic occlusion during experimental hepatic vascular exclusion. Am J Surg, submitted.]

estimation were attenuated. ${ }^{41,42}$ Phosphate buffer solutions have been suggested as options to improve the accuracy and reliability of $\mathrm{PCO}_{2}$ measurement. ${ }^{43}$

However, the use of systemic bicarbonate, assuming that it is equal to intramucosal bicarbonate concentration, is the major limitation for the use of calculated $\mathrm{pHi}$ in the clinical setting. Isolated regional ischemia may result in lower local bicarbonate levels when compared to systemic values. Conversely, during shock states with systemic acidosis, gastric intramucosal bicarbonate is consistently greater than that of arterial blood. Moreover, other causes of systemic hypercarbia and metabolic acidosis, without hypoperfusion, may also influence pHi calculation, despite a preserved mucosal perfusion. For all those drawbacks, calculated pHi should be replaced by the tonometer-arterial blood $\mathrm{PCO}_{2}$ gradient, named $\mathrm{PCO}_{2}$ gap, avoiding the confounding effects of systemic metabolic and respiratory alterations. However, Guzman et al. ${ }^{44}$ showed that this gradient remains stable during hypoventilation, but it may increase after hyperventilation. These findings warrant cautious interpretation of $\mathrm{PCO}_{2}$ gap as an indicator of gastric

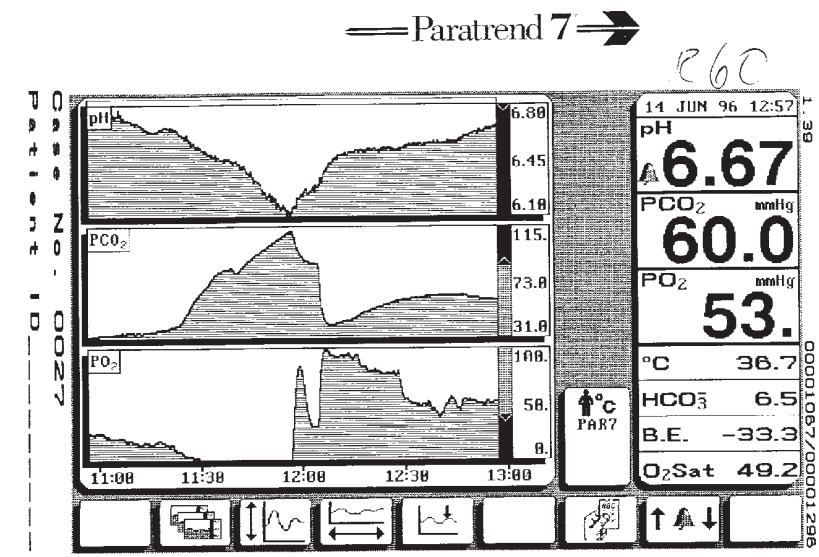

Figure 5 - Representative tracing of the effects of descending aortic cross-clamping followed by a 60 -min reperfusion period on the bladder mucosal $\mathrm{pH}, \mathrm{PO}_{2}$ and $\mathrm{PCO}_{2}$, measured continuously with a Paratrend 7 chemical probes in pigs. Lower torso ischemia promoted a sharp decrease in bladder mucosal $\mathrm{pH}$ and $\mathrm{PO}_{2}$, while mucosal $\mathrm{PCO}_{2}$ showed a marked increase. Reperfusion was associated with a progressive $\mathrm{pH}$ restoration, a sustained increased $\mathrm{PO}_{2}$ from reactive hyperemia, and a sudden decrease in bladder mucosal $\mathrm{PCO}_{2}$, followed by a clear increase, suggesting reperfusion injury [adapted from de Lang JD, Evans DJ, Poli de Figueiredo $L F$ et al. A novel approach to monitor tissue perfusion: bladder mucosal $P C O, P O$, and $\mathrm{pHi}$ during ischemia and reperfusion in pigs. J Intensive Care 1999; 14:93-98] 
mucosal perfusion during systemic hypocapnia. Despite this concern, $\mathrm{PCO}_{2}$-gap remains the most reliable marker of tissue perfusion nowadays and should definitively replace $\mathrm{pHi}^{45,46}$

Further advances in the tonometric method were achieved by Salzman et al., ${ }^{21}$ who reinvestigated the concept that $\mathrm{PCO}_{2}$ measurements could be performed on gas aspirated from the stomach. The $\mathrm{PCO}_{2}$ of this gas correlated with that measured on saline sampled from a conventional balloon tonometer, when perfusion was decreased by pericardial tamponade. During respiratory acidosis and in the absence of shock, there was a very high correlation between the $\mathrm{PCO}_{2}$ of stomach gas and that of the saline sampled from the balloon. This concept of air tonometry was recently expanded by Guzman and Kruse, ${ }^{47}$ who circulated gas through a gastric balloon and measured $\mathrm{PCO}_{2}$ continuously, by an infrared capnometer. More recently, capnometry and conventional balloon tonometry have been combined and called capnometric recirculating gas tonometry (CRGT), overcoming limitations such as the long equilibration time, saline sampling and a relatively labor-intensive manipulation. Air is used in lieu of saline, and then gas is aspirated and analyzed automatically by infrared capnometry after a 10-minute equilibration, with a commercially available Tonocap (Datex-Engstrom; Tonometrics; Tewksbury, Mass). In experimental models, CRGT has been shown to be capable of detecting changes in gastric mucosal $\mathrm{PCO}_{2}$ shortly after inducing hypoxemia and hemorrhage. ${ }^{47}$ CRGT has been also validated in critically ill patients. ${ }^{13,48}$ Hence, CRGT is actually the best method that, in addition to provide semi-continuous online measurements of gastric $\mathrm{PCO}_{2}$, can detect significant changes within minutes, and may be used during short-term interventional studies.

\section{PCO, AS A MARKER OF BLOOD FLOW AND TISSUE HYPOXIA}

In animal models of progressive hemorrhage or cardiac tamponade, in which $\mathrm{DO}_{2}$ was reduced by a decreased cardiac output, an elevation in veno-arterial $\mathrm{DPCO}_{2}$ was observed, while $\mathrm{VO}_{2}$ and $\mathrm{CO}_{2}$ production remained constant. ${ }^{50-52}$ In this condition of oxygen supply-independency, an elevation of veno-arterial $\mathrm{DPCO}_{2}$, following flow reduction, can be explained simply by $\mathrm{CO}_{2}$ stagnation. When $\mathrm{DO}_{2}$ was further reduced, below its critical value ( $\mathrm{DO}_{2}$ crit), a decrease in $\mathrm{VO}_{2}$ was observed, suggesting oxygen supplydependency and consequent anaerobic metabolism. An increase in lactate concentration confirmed this assumption. ${ }^{51,52}$ The progressive widening of venoarterial $\mathrm{DPCO}_{2}$ was magnified by a sharp increase in
$\mathrm{PvCO}_{2}$, when $\mathrm{DO}_{2}$ decreased below its critical point (a veno-arterial $\mathrm{DPCO}_{2}$ around $30 \mathrm{mmHg}$ ). It was assumed that this steep increase in $\mathrm{DPCO}_{2}$ can be used as a reliable marker of tissue dysoxia, since $\mathrm{DO}_{2}$ crit, calculated by either using the relationship between $\mathrm{VO}_{2}$ to $\mathrm{DO}_{2}$, lactate to $\mathrm{DO}_{2}$, or $\mathrm{DPCO}_{2}$ to $\mathrm{DO}_{2}$, provided similar results. ${ }^{51,52}$

However, in a recent review, Teboul et al. ${ }^{53}$ noticed that the aerobic production of $\mathrm{CO}_{2}$ is theoretically reduced when tissue dysoxia is present (as $\mathrm{VCO}_{2}=\mathrm{R}$ $\mathrm{x} \mathrm{VO}_{2}$ ), and proposed that an explanation of venous and tissue hypercarbia, in low-flow states, emerges from the curvilinearity of the Fick equation. As mentioned above, if anaerobic $\mathrm{CO}_{2}$ production occurred under conditions of tissue dysoxia, it would result from the $\mathrm{H}^{+}$excess buffering by $\mathrm{HCO}_{3}^{-}$. However, as highlighted by Teboul et al., ${ }^{53}$ studies addressing the issue of detecting tissue dysoxia by analysis of $\mathrm{DPCO}_{2}$, used experimental protocols of blood flow reduction; the associated decrease in cardiac output acts as a confounding variable, not allowing a definitive conclusion. In order to clarify this question, Vallet et al., ${ }^{54}$ using an in situ isolated, innervated canine hind limb model, showed that when $\mathrm{DO}_{2}$ was decreased, either by blood flow reduction (ischemic hypoxia) or decreasing arterial $\mathrm{PO}_{2}$ (hypoxic hypoxia), regional veno-arterial $\mathrm{DPCO}_{2}$ increased only when blood flow was reduced, even though the same oxygen deficit was observed in both protocols. The authors conclude that the absence of an increased veno-arterial $\mathrm{DPCO}_{2}$ does not preclude the presence of tissue dysoxia. Hence, decreased blood flow appeared to be the major determinant of increased $\mathrm{DPCO}_{2}$.

If intestinal tonometry is to be used to detect early dysoxia in low flow states, it is essential to know at which level increased tissue $\mathrm{PCO}_{2}$ represents aerobic (stagnant flow with preserved $\mathrm{VO}_{2}$ ) or anaerobic metabolism. Some evidences have emerged from Schlichtig's group studies. ${ }^{23}$ These authors observed that mucosal $\mathrm{PCO}_{2}$, estimated by tonometry, increased to values nearly threefold higher than predicted by Dill's blood nomogram, which shows the aerobic relationship between $\mathrm{PvCO}_{2}$ and $\mathrm{SvO}_{2}$. In this nomogram, a known $\mathrm{PvCO}_{2}$ can be used to predict $\mathrm{SvO}_{2}\left(\mathrm{SvO}_{2}{ }^{\text {Dill }}\right)$. A SvO ${ }_{2}^{\text {Dill }}$ that agrees with a measured $\mathrm{SvO}_{2}$ in a blood sample indicates that dissolved $\mathrm{CO}_{2}$ appeared purely on the basis of aerobic metabolism. On the other hand, when $\mathrm{SvO}_{2}$ Dill is less than the measured $\mathrm{SvO}_{2}$, it represents the conversion of $\mathrm{HCO}_{3}^{-}$to dissolved $\mathrm{CO}_{2}$, due to an anaerobic metabolism. Moreover, these authors also observed that gastric mucosal $\mathrm{PCO}_{2}$ markedly exceeded $\mathrm{PCO}_{2}$ values in portal venous blood, when flow was decreased below the critical $\mathrm{DO}_{2}$. Consistency with 
aerobic $\mathrm{CO}_{2}$ was only observed with a maximal mucosal-arterial $\mathrm{DPCO}_{2}$ gradient, around 25-35 mmHg, while a further increase in mucosal-arterial $\mathrm{DPCO}_{2}$ was consistent with mucosal dysoxia. However, in this particular study, low blood flow remained as a confounding variable, according to Teboul's experiments. ${ }^{53}$

To establish the exact role of a decreased blood flow on tissue $\mathrm{PCO}_{2}$, Vallet et al. ${ }^{55}$ evaluated veno-arterial $\mathrm{CO}_{2}$ gap $\left[\mathrm{P}(\mathrm{v}-\mathrm{a}) \mathrm{CO}_{2}\right]$, gut mucosal-arterial $\mathrm{CO}_{2}$ gap $\left[\mathrm{P}(\mathrm{m}-\mathrm{a}) \mathrm{CO}_{2}\right]$, and gastric mucosal blood flow (laser Doppler flow probe). They showed, by using two different mechanisms of tissue hypoxia, that mucosal blood flow is not the only factor that could contribute to gastric mucosal hypercarbia. In one group, systemic hypoxia was induced by progressive reduction in the inspired oxygen fraction (hypoxic hypoxia, $\mathrm{HH}$ ) or by progressive bleeding (ischemic hypoxia, IH). While $\mathrm{IH}$ decreased gastric mucosal blood flow and increased both $\left[\mathrm{P}(\mathrm{v}-\mathrm{a}) \mathrm{CO}_{2}\right]$ and $\left[\mathrm{P}(\mathrm{m}-\mathrm{a}) \mathrm{CO}_{2}\right], \mathrm{HH}$ increased only $\left[\mathrm{P}(\mathrm{m}-\mathrm{a}) \mathrm{CO}_{2}\right]$, although gastric mucosal blood flow remained constant. As expected, IH induced a larger increase in $\mathrm{DPCO}_{2}$ than $\mathrm{HH}$. The peculiar microcirculatory system and its counter-current exchange of oxygen and $\mathrm{CO}_{2}$ within mucosal villus could explain these findings (Figure 1). Therefore, conditions of low tissue $\mathrm{DO}_{2}$ may induce both tissue hypoxia and hypercarbia, by incrementing the counter-current oxygen exchange between arteriole and venule, threatening cells at the tips of the villi.

Following fluid resuscitation in sepsis or hemorrhage, tissue $\mathrm{DO}_{2}$ may be restored but gastric mucosal hypercarbia may be not prevented, due to disturbances in cellular metabolic pathways impairing oxygen utilization, which has been named cytopathic hypoxia. ${ }^{54,55}$ This may explain the concomitance of high tissue $\mathrm{PCO}_{2}$ and adequate tissue $\mathrm{PO}_{2}$ and gastric mucosal blood flow, observed by several authors. ${ }^{25,56,57}$ In fact, a high gastric to arterial $\mathrm{PCO}_{2}$ gradient could be a marker of dysoxia, independent of the causes of impaired oxygen utilization.

However, a simplistic conclusion that tissue hypercarbia means necessarily hypoperfusion or anaerobic metabolism may be misleading. The rational behind tonometry is the assumption that an increased mucosal-arterial $\mathrm{PCO}_{2}$ gradient indicates imbalance between perfusion and metabolism. This assumes that the mucosal-arterial $\mathrm{PCO}_{2}$ gradient is a surrogate marker of mucosal-arterial $\mathrm{CO}_{2}$ content difference. However, when oxygen saturation, hemoglobin and/or arterialvenous $\mathrm{pH}$ difference change, the relationship between $\mathrm{PCO}_{2}$ and $\mathrm{CO}_{2}$ content is not linear. In particular, the condition in which there is an increase in blood flow, but a larger increase in $\mathrm{CO}_{2}$ production, matching a respective change in oxygen consumption, may lead to the dissociation of $\mathrm{PCO}_{2}$ gradients between vascular beds with different baseline oxygen extraction. Jakob et al. ${ }^{58}$ have speculated that, particular changes in tissue oxygen extraction (Haldane effect), may explain the increasing mucosal-arterial $\mathrm{PCO}_{2}$ gradients, despite preserved or increased mucosal tissue perfusion.

In summary, the major determinant of tissue $\mathrm{PCO}_{2}$ is blood flow. However, because of the villi's peculiar vascular arrangement, a high gastric mucosal $\mathrm{PCO}_{2}$ can be a marker of dysoxia and not simply a marker of disproportional low blood flow to tissue metabolic status.

\section{CONCLUSION}

There are clinical and experimental evidences that support the relationship between splanchnic hypoperfusion and multiple organ dysfunction in patients and animals submitted to trauma or major surgical procedures, largely related to mucosal injury leading to increased permeability and systemic inflammatory response. As gut mucosal $\mathrm{pCO}_{2}$ reflects the balance between flow and metabolism, gas tonometry is a valuable tool to monitor regional effects of hemodynamic interventions and gives insights regarding blood flow heterogeneity in distinct shock states. Next issue we will be presenting our experience with gas tonometry in experimental and clinical sepsis. ${ }^{59}$ The definitive role of gas tonometry to predict outcome and guide therapy for patients with trauma, sepsis or submitted to complex operations, will be established by large, prospective multicenter trials.

\section{REFERENCES}

1. Schumacker P, Cain SM. The concept of a critical oxygen delivery. Intensive Care Med 1987;13:223-9.

2. Ince C, Sinaasappel M. Microcirculatory oxygenation and shunting in sepsis and shock. Crit Care Med 1999;27:136977.

3. Vallet B, Lund N, Curtis SE, et al. Gut and muscle tissue PO2 in endotoxemic dogs during shock and resuscitation. J Appl Physiol 1994;76:793-800.

4. Marshall JC, Christou NV, Meakins JL. The gastrointestinal tract: the "undrained abscess" of multiple organ failure. Ann Surg 1993;218:111-9.

5. Guyton AC, Hall J. General principles of gastrointestinal function: motility, nervous control, and blood circulation. In: Guyton AC, Hall JE. Textbook of medical physiology. 9ed. 1996. p 793-802.

6. Nelson DP, Samsel RW, Wood LD, Schumacker P. Pathological supply dependence of systemic and intestinal O2 uptake during endotoxemia. J Appl Physiol 1988;64:2410-9.

7. Fink MP. Why the GI tract is pivotal in trauma, sepsis, and MOF. Sepsis 1991;6:253-76. 
8. Mythen M, Faehnrich J. Monitoring gut perfusion. In: Rombeau JL, Takala J. Gut dysfunction in critical illness. Springer-Verlag: Berlin; 1996. p 246-63.

9. Fiddian-Green RG. Gastric intramucosal pH, tissue oxygenation and acid-base balance. Br J Anaesth 1995;74(5):591-606.

10. McIver M. Gaseous exchange between the blood and the lumen of the stomach and intestine. Am J Physiol 1926;76:92-111.

11. Boda D, Muranyi L. "Gastrotonometry": an aid to the control of ventilation during artificial respiration. Lancet 1959;73:181-2.

12. Bergofsky EH. Determinationof of tissue O2 tensions by hollow visceral tonometers: effects of breathing enriched $\mathrm{O} 2$ mixtures. J Clin Invest 1964;43:193-200.

13. Dawson AM, Trenchard D, Guz A. Small bowel tonometry: assessment of small gut mucosal oxygen tension in dog and man. Nature 1965;206:943-4.

14. Creteur J, De Backer D, Vincent JL. Monitoring gastric mucosal carbon dioxide pressure using gas tonometry: in vitro and in vivo validation studies. Anesthesiology 1997;87:504-10.

15. Fiddian-Green RG. Tonometry: theory and applications. Intensive Care World 1992;9:60-5.

16. Antonsson JB, Engstrom L, Rasmussen I, Wollert S, Haglund $\mathrm{UH}$. Changes in gut intramucosal $\mathrm{pH}$ and gut oxygen extraction ratio in a porcine model of peritonitis and hemorrhage. Crit Care Med 1995;23:1872-81.

17. Antonsson JB, Boyle CC, Kruithoff KL, Wang HL, Sacristan E, Rothschild HR et al. Validation of tonometric measurement of gut intramural $\mathrm{pH}$ during endotoxemia and mesenteric occlusion in pigs. Am J Physiol 1990;259(4 Pt 1):G519-23.

18. Montgomery A, Hartmann M, Jonsson K, Haglund U. Intramucosal $\mathrm{pH}$ measurement with tonometers for detecting gastrointestinal ischemia in porcine hemorrhagic shock. Circ Shock 1989; 29:319-27.

19. Antonsson JB, Haglund UH. Gut intramucosal pH and intraluminal $\mathrm{PO} 2$ in a porcine model of peritonitis or haemorrhage. Gut 1995; 37:791-7.

20. Schlichting E, Lyberg T. Monitoring of tissue oxygenation in shock:an experimental study in pigs. Crit Care Med 1995; 23:1703-10.

21. Salzman AL, Strong KE, Wang H, Wollert PS, Vandermeer TJ, Fink MP. Intraluminal balloonless air tonometry: a new method for determination of gastrointestinal mucosal carbon dioxide tension. Crit Care Med 1994; 22:126-34.

22. Sato Y, Weil MH, Tang W, Sun S, Xie J, Bisera J et al. Esophageal $\mathrm{PCO} 2$ as a monitor of perfusion failure during hemorrhagic shock. J Appl Physiol 1997; 82:558-62.

23. Schlichtig R, Bowles SA. Distinguishing between aerobic and anaerobic appearance of dissolved $\mathrm{CO} 2$ in intestine during low flow. J Appl Physiol 1994;76:2443-51.

24. Tang W, Weil MH, Sun SJ, et al. Gastric intramural PCO2 as a monitor of perfusion failure during hemorrhagic and anaphylatic shock. J Appl Physiol 1994;76:572-7.

25. van der Meer JT, Wang H, Fink MP. Endotoxemia causes ileal micosal acidosis in the absence of mucosal hypoxia in a normodynamic porcine model of septic shock. Crit Care Med 1995;23:1217-26.

26. Heino A, Hartikainen J, Merasto M, Alhava E, Takala J. Systemic and regional PCO2 gradients as markers of intestinal ischaemia. Intensive Care Med 1998;24:599-604.

27. Knichwitz G, Rotker J, Mollhoff T, Richter KD, Brussel T Continuous intramucosal PCO2 measurement allows the early detection of intestinal malperfusion. Crit Care Med 1998;26:1550-7.

28. Neviere R, Chagnon JL, Vallet B, et al. Dobutamine improves gastrointestinal mucosal blood flow in a porcine model of endotoxic shock. Crit Care Med 1997; 25:1371-7.
29. Neviere R, Mathieu D, Chagnon JL, Lebleu N, Wattel F. The contrasting effects of dobutamine and dopamine on gastric mucosal perfusion in septic patients. Am J Respir Crit Care Med 1996;154(6 Pt 1):1684-8.

30. Elizalde JI, Hernandez C, Llach J, Monton C, Bordas JM, Pique JM et al. Gastric intramucosal acidosis in mechanically ventilated patients: role of mucosal blood flow [see comments]. Crit Care Med 1998; 26(5):827-32.

31. Fiddian-Green RG, Pittenger G, Whitehouse WM Jr. Backdiffusion of $\mathrm{CO} 2$ and its influence on the intramural $\mathrm{pH}$ in gastric mucosa. J Surg Res 1982;33:39-48.

32. Heard SO, Helmsoortel CM, Kent JC, et al. Gastric tonometry in health volunteers:effect of ranitidine on calculated intramural pH. Crit Care Med 1991;19:271-4.

33. Kolkman JJ, Groeneveld AB, Meuwissen SG. Effect of ranitidine on basal and bicarbonate enhanced intragastric PCO2: a tonometric study. Gut 1994;35(6):737-41.

34. Stevens MH, Thirlby RC, Feldman M. Mechanisms for high $\mathrm{PCO} 2$ in gastric juice:roles of bicarbonate secretion and $\mathrm{CO} 2$ diffusion. Am J Physiol 1987;253[(4 Pt 1)]:G527-30.

35. Driks MR, Graven DE, Celli BR, et al. Nosocomial pneumonia in intubated patients given sucralfate as compared with antacids or histamine type 2 blockers: the role of gastric colonization. N Engl J Med 1987;317:1376-82.

36. Jin X, Weil MH, Sun S, Tang W, Bisera J, Mason EJ. Decreases in organ blood flows associated with increases in sublingual PCO2 during hemorrhagic shock. J Appl Physiol 1998;85:2360-4.

37. Weil MH, Nakagawa Y, Tang W, Sato Y, Ercoli F, Finegan R et al. Sublingual capnometry: a new noninvasive measurement for diagnosis and quantitation of severity of circulatory shock. Crit Care Med 1999;27:1225-9.

38. Nakagawa Y, Weil MH, Tang W, Sun S, Yamaguchi H, Jin X et al. Sublingual capnometry for diagnosis and quantitation of circulatory shock. Am J Respir Crit Care Med 1998;157(6 Pt 1):1838-43.

39. Lang JD, Evans D, Poli de Figueiredo L, Hays S, Mathru M, Kramer G. A novel approach to monitor tissue perfusion: bladder mucosal PCO2, PO2, and pHi during ischemia and reperfusion in pigs. J Intensive Care 1999;14:93-8.

40. Kette F, Weil MH, Gazmuri RJ, et al. Intramyocardial hyperbaric acidosis during cardiac arrest and resuscitation. Crit Care Med 1993;21:901-6.

41. Takala J, Parviainen I, Siloaho M, Ruokonen E, Hamalainen E. Saline PCO2 is an important source of error in the assessment of gastric intramucosal pH. Crit Care Med 1994; 22(11):1877-9.

42. Riddington D, Venkatesh B, Clutton-Brock T, Bion J, Venkatesh $\mathrm{KB}$. Measuring carbon dioxide tension in saline and alternative solutions: quantification of bias and precision in two blood gas analyzers [published erratum appears in 1994 Apr;22(4):722]. Crit Care Med 1994; 22(1):96-100.

43. Knichwitz G, Kuhmann M, Brodner G, Mertes N, Goeters C, Brussel T. Gastric tonometry: precision and reliability are improved by a phosphate buffered solution. Crit Care Med 1996;24:512-6.

44. Guzman JA, Kruse JA. Gut mucosal-arterial PCO2 gradient as an indicator of splanchnic perfusion during systemic hypoand hypercapnia. Crit Care Med 1999;27:2760-5.

45. Schlichtig R, Mehta N, Gayowski TJ. Tissue-arterial PCO2 difference is a better marker of ischemia than intramural $\mathrm{pH}$ (pHi) or arterial pH-pHi difference. J Crit Care 1996;11:51-6.

46. Vincent JL, Creteur J. Gastric mucosal $\mathrm{pH}$ is definitely obsolete - please, tell us more about gastric mucosal PCO2 [editorial]. Crit Care Med 1998;26:1479-81.

47. Guzman JA, Kruse JA. Development and validation of a technique for continuous monitoring of gastric intramucosal pH. Am J Respir Crit Care Med 1996;153(2):694-700. 
48. Guzman JA, Kruse JA. Continuous assessment of gastric intramucosal $\mathrm{PCO} 2$ and $\mathrm{pH}$ in hemorrhagic shock using capnometric recirculating gas tonometry. Crit Care Med 1997;25:533-7.

49. Heinonen PO. Validation of air tonometric measurement of gastric regional concentration of $\mathrm{CO} 2$ in critically ill septic patients. Intensive Care Med 1997;23:524-9.

50. Bowles SA, Schlichtig R, Kramer DJ, Klions HA. Arteriovenous $\mathrm{pH}$ and partial pressure of carbon dioxide detect critical oxygen delivery during progressive haemorrhage in dogs. J Crit Care 1992;7:95-105.

51. Van Der Linden P, Rausin I, Deltell A, et al. Detection of tissue hypoxia by arteriovenous gradient for $\mathrm{PCO} 2$ and $\mathrm{pH}$ in anesthetized dogs during progressive hemorrhage. Anesth Analg 1995;80:269-75.

52. Zhang H, Vincent JL. Arteriovenous difference in PCO2 and $\mathrm{pH}$ are good indicators of critical hypoperfusion. Am Rev Respir Dis 1993;148:867-71.

53. Teboul JL, Michard F, Richard C. Critical analysis of venoarterial $\mathrm{CO} 2$ gradient as a marker of tissue hypoxia. In: Vincent JL. Yearbook of intensive care and emergency medicine. SpringerVerlag: Berlin; 1996. p 296-307.
54. Vallet B, Teboul JL, Cain SM, Curtis SE. Veno-arterial CO2 difference during regional ischemic or hypoxic hypoxia. J Appl Physiol 2000;89:1317-21.

55. Vallet B, Durinck JL, Chagnon JL, Neviere R. Effects of hypoxic hypoxia on veno and gut mucosal arterial PCO2 difference in pigs. Anesthesiology 1996;85:A607.

56. Temmesfeld-Wollbruck B, Szalay A, Mayer K, Olschewski H, Seeger W, Grimminger F. Abnormalities of gastric mucosal oxygenation in septic shock: partial responsiveness to dopexamine. Am J Respir Crit Care Med 1998;157(5 Pt 1):1586-92.

57. Revelly JP, Ayuse A, Brienza N, et al. Endotoxic shock alters distribution of blood flow within the intestinal wall. Crit Care Med 1996;24:1345-51.

58. Jakob SM, Kosonen P, Ruokonen E, Parviainen I, Takala J. The Haldane effect - an alternative explanation for increasing gastric mucosal PCO2 gradients? Br J Anaesth 1999; 83:740-6.

59. Silva E, Poli de Figueiredo LF, Cruz Jr RJ, Rocha e Silva M. Gas tonometry for evaluation of gastrointestinal mucosal perfusion: experimental and clinical sepsis. Part 2. Acta Cir Bras 2002;17(5): (in press)

Poli de Figueiredo LF, Silva E, Cruz Jr RJ, Rocha e Silva M. Tonometria a gás para a avaliação da perfusão da mucosa gastrointestinal: modelos experimentais de trauma, choque e manobras cirúrgicas complexas. Parte 1. Acta Cir Bras [serial online] 2002 Jul-Ago;17(4). Disponível em URL: http:// www.scielo.br/acb

RESUMO - Evidências clínicas e experimentais substanciais indicam que o território circulatório mesentérico, principalmente na mucosa intestinal, é altamente vulnerável a redução na oferta de oxigênio e predisposto a lesão precoce na presença de alterações hemodinâmicas induzidas por trauma, choque, sepse e diversas manobras cirúrgicas complexas. A hipóxia ou isquemia intestinal é um dos possíveis mecanismos contribuintes para a disfunção da barreira gastrointestinal que pode estar associada com o desenvolvimento da resposta inflamatória sistêmica e com a síndrome da disfunção de múltiplos órgãos, causa comum de morte após trauma, sepse ou cirurgias de grande porte. Monitorar a perfusão intestinal em experimentos pode fornecer dados valiosos quanto a novas intervenções e tratamentos altamente necessários para reduzir a morbidade e mortalidade extremamente elevadas no trauma e na sepse. Apresentamos nossa experiência com a tonometria a gás como monitor da adequação da perfusão da mucosa gastrointestinal clínica e experimental, em modelos de trauma, sepse, e manobras cirúrgicas complexas tais como a oclusão da aorta e a exclusão vascular hepática.

DESCRITORES - Isquemia. Reperfusão. Tonometria. Choque séptico. Falência de múltiplos órgãos. Catecolaminas. Mucosa intestinal. Sepse. Traumatismo múltiplo.

Conflito de interesse: nenhum Fonte de financiamento: FAPESP

Address for correspondence:

Luiz F Poli de Figueiredo

Heart Institute (InCor), Univ. São Paulo Medical School

Av. Enéas de Carvalho Aguiar, 44

05403-000 São Paulo - SP

Phone: (55)11-3069-5297

Fax: (55)11-3068-9955

expluiz@incor.usp.br

Data do recebimento: $28 / 02 / 2002$

Data da revisão: 21/03/2002

Data da aprovação: 15/04/2002 